\title{
Spatial Impact of Extension Workers' Performance on Sustainable Agricultural Development in Kaduna State of Nigeria
}

\author{
Adefila, J. O. \\ Department of Geography, Ahmadu Bello University, Zaria, Nigeria \\ Tel: 234-803-830-9791Ｅ-mail: olufiladr@yahoo.com
}

Received: October 13, 2011

Accepted: March 5, $2012 \quad$ Published: April 1, 2012

doi:10.5539/jsd.v5n4p141

URL: http://dx.doi.org/10.5539/jsd.v5n4p141

\begin{abstract}
The study examined the performance of extension workers with respect to agricultural development in Kaduna State among the sampled agricultural extension workers. The study aimed at assessing the attitudes of the workers to job performance and identifying factors that enhance performance among workers in the study area. Primary data were collected from a sample of 60 agricultural extension workers. The study area has six extension stations at different locations. In each station, ten samples were taken adopting purposive sampling technique. The sample is believed to be adequate to reflect the opinion of entire extension workers. The non-parametric Chi Square technique and descriptive statistics were adopted to analyse the data. The study showed that majority of the extension workers $66.7 \%$ were married and males fell within the age-group of 21 and 40 years. The educational level was relatively average as $36.7 \%$ had either Ordinary National Diploma or Nigeria Certificate of Education (NCE). Indeed, only $20 \%$ claimed that the income was adequate. However, the job performance score was high as $75 \%$. There were divergent opinions about some impediments that affected the job performance such as poor condition of service, irregular wages and allowances, and inadequacy of important materials and equipment to execute the work. The attitude of majority of the workers towards their job was found to be encouraging. The statistical test showed that there was a significant difference between level of education, attitude and the job performance of the extension workers at 0.05 alpha level. On the basis of the findings, one recommends that ministries and agencies concerned should address the constraints that affect agricultural extension workers' performance once and for all and it will go a long way to boost job performance. Moreover, improvement in attitude of workers can as well result in a remarkable increment in agricultural productivity.
\end{abstract}

Keywords: Agriculture, Extension worker, Sustainability development

\section{Introduction}

Perhaps it is the first time that Federal government recognized the spatial dichotomy among the regions in Nigeria when it made a policy statement in the Second National Development Plan that there is need to ameliorate inequality through appropriate policy measures within the content of a general belief that 'a just and egalitarian society, puts premium on reducing inequality in interpersonal incomes and promoting a balanced development among the various communities in different geographical areas of the country (Nigeria, 1970-74:32-36). A similar policy stipulated in the same document is the promotion of balanced development between one part of the country and another especially between the urban and rural areas. The rural areas have suffered untold hardships in terms of deprivation and neglect. Olatunbosun (1995) simply remarked that Nigeria neglected rural majority. A part from forming an important sector of the national economy, majority of the people live in rural areas and therefore, the future prospects of the country depends on rural areas for agricultural development. Adefila (2008) had remarked that the rural sector constitutes the social and economic environment of the total population such that if it is not developed and set moving, many of the objectives of development programmes will be frustrated. It is not surprising therefore, the policies and strategies for rural development to be inept. Adisa and Okunade (2005) had remarked that about 80 percent of the population lives directly or indirectly on the resources of the land. It was observed that in spite of the growing importance of other sectors such as oil and gas and manufacturing, agriculture still accounts for a substantial percentage of the Gross Domestic Product (GDP), employs the largest labour force, the principal source of food and raw materials for feeding the light industries. Igbokwe et al. (1995) noted that the problem of rural development cannot be viewed as a narrow technical problem of increasing agricultural output, but establishing appropriate institutions to 
mobilize and induce rural communities to greater productivity, to help them overcome the constraints in the way of utilizing available resources, and enabling them to distribute the development benefits equitably among regions. Indeed, virtually all efforts being made by successive governments in Nigeria towards socio-economic transformation of the rural communities have not yielded meaningful results (Adefila, 2008). In history, government had put in place agricultural strategies such as input subsidy, institutional reforms, marketing boards, agricultural banks and extension workers with a view to improving living conditions in the rural areas. To the dismay of policy makers and planners, rural people continue to suffer from abject poverty. This situation informed the government that agriculture alone does not make up the rural economy but also other infrastructural facilities must be injected into the region hence, river basin development authority (RBD) and integrated rural development strategies were introduced. It is a multi-dimensional approach that incorporates not only agriculture but also roads, small-scale industries, water supply and electricity. Feder and Roger (2002) conceived agricultural extension workers as a link between the research institutes and the farmers at the community levels. The government legislation that established agricultural extension workers had in principle to demonstrate before the rural farmers new techniques of farming with a view to boosting agricultural productivity. Jibowo (2005) remarked that extension workers are important agents of change and development in the country especially at the community or grassroots .and improving quality of life in their respective locations.

Birkhaeuser (1991) remarked that the extension workers must be better equipped for rural needs by virtue of their training, the proximity to the grassroots, their ability to identify felt needs of the rural communities and their efficient and cost effective mode of operation. Baba (1988) had said that agricultural extension workers owe their existence to the government policy within the context of administrative structures provided and its mandate was to act as agent of change in the process of agricultural transformation. To achieve the set goals, there must be material and human resources on deck so as to achieve high productivity. Considering the importance of extension workers in complementing government's efforts in agricultural development, Ogunfiditimi et al. (1995) stressed the need to assist rural people to achieve development and the importance of the human resource in harnessing the organizational objectives and therefore the need for an empirical insight into the performance of these category of workers in Nigeria, particularly, their socio-economic characteristics, factors that promote job performance, constraints to job performance and the workers' attitudes towards their jobs.

\section{Conceptual Framework of Study}

There are two fundamental concepts that demand clarification for the understanding of this research work and they are - concepts of sustainability and Agricultural extension. Each concept is explained below.

\subsection{Agricultultural Extension}

It was known as the application of scientific research and new knowledge to agricultural practices through farmer education. Purcell and Anderson (1997) observed that field of extension now encourages a wider range of communication and learning activities organized for rural people by professionals from different disciplines, including agriculture, agricultural marketing, health, and business studies. Extension practitioners can be found throughout the world usually working for government agencies. Agricultural extension agencies in developing countries have received large amount of support from international development organizations such as the World Bank and the Food and Agriculture Organization (FAO) of the United Nations.

The term extension was first used to describe adult education programmes in England in the second half of the $19^{\text {th }}$ century. The programmes helped to extend the work of the universities beyond the campuses and into the neighbouring communities. The term was later adopted in the United States of America, while in Britain it was replaced with 'advisory service' in the $20^{\text {th }}$ century (Bindlish \& Robert, 1993). A number of other terms are identified by Umali-Deninger (1997) used in different parts of the world to describe the same or a similar concept such as 'guidance' 'lighting the path' 'advisory work' 'simplification' 'improving skills' and 'promoting'. Umali-Deninger (1997) remarked that in United States of America, an extension agent is university employee who develops and delivers educational programmes to assist people in economic, community development, leadership, family issues, agriculture and environment. Extension agents provide cooperative extension service at land-grant universities. They are sometimes referred to as country agents or educators.

Indeed, there is no widely accepted definition of agricultural extension. Madukwe (1995) remarked that the central task of extension is to help rural families help themselves by applying science, whether physical or social to the daily routings of farming, home-making and family and community living. Madukwe (1995) also described agricultural extension as a system of out-of-school education for rural people. Atta-Krah (1990) had ealier remarked that extension personnel have the task of bringing scientific knowledge to farm families in the 
farms and homes. The object of the task is to improve the efficiency of agriculture. Appleton and Arsene (1996) noted that extension is a service or system which assists farm people, through educational procedures, in improving farming methods and techniques, increasing production efficiency and income, bettering their levels of living and lifting social and educational standards. Jones (1997) remarked that extension involves the conscious use of communication of information to help people form sound opinions and make good decisions. Moreover, he viewed Agricultural extension as assistance to farmers to help them identify and analyze their production problems and become aware of the opportunities for improvement. World Bank (1990) simply puts it as Agricultural communication intervention deployed by an institution to induce change in voluntary behaviours with a presumed public or collective utility. Beti-Thompson et al. (1995) saw extension as the organized exchange of information and the purposive transfer of skills. Beti remarked that the essence of agricultural extension is to facilitate interplay and nurture synergies within a total information system involving agricultural research, agricultural education and a vast complex of information-providing businesses.

\subsection{Sustainability}

The concept of sustainability relates to survival, keeping the economy alive. However, to achieve this, the main requirement is provision of sufficient food and which can only be possible through agriculture. With the help of increased means of production and greater efficiency in production attempts are made to meet the growing demand of the teeming population. Kuhnen (2002) had taken the concept of sustainability to mean an ecological acceptable production, where everything removed is then replaced so as not to harm the ecological system. This thought is likened to a traditional farmer, who with self-image as trustee of his farm and supposed to use, preserve, enlarge and then pass on to his descendants as in other cultures. But unfortunately, of recent, the advent of technological innovations, communication and transport systems have led to changes in traditional attitude and behaviour of man towards his environment (Adefila, 2011).

The term sustainability could also mean a thriving economic and social order with production structures and relationships which ensure a fair distribution of income, power and opportunities, thereby providing the much needed social justice and peace in the society. Sustainability could mean a sense of long-term carrying capacity of regions where there is no negative impact on the environment. Indeed, this is the summary of the other three definitions of sustainability. Put together, sustainability means provision of sufficient food and consumer goods coming from ecologically acceptable production in a well-functioning economic and social system provide the conditions for the long-term carrying-capacity of a region (Kuhnen, 2002).

\section{Methodology}

In this section, the types of data, sources of data, sample size, sampling technique and analytical techniques were discussed.

\subsection{Data Selection}

The data selected for the study were carefully chosen in order to enhance reliable results and they include:

i. The data on the traits of agricultural extension workers in the study area.

ii. The attitudes of the agricultural extension workers towards the role specification.

iii. The problems confronting the respondents.

iv. Data on how to improve the condition of service of the extension workers.

\subsection{Sources of Data}

Both primary and secondary sources of data were employed in this study. The primary data were collected through oral and written interviews. Agricultural extension workers were interviewed in form of focus group discussion (FGD). This method affords gathering of essential information from those that are directly engaged in agricultural development process. In order to validate the research instrument a well-structured questionnaire was given to experts in agricultural economics and the instrument was found to be reliable at a confidence coefficient of 0.85 . The questionnaire was administered among the extension workers by adopting a random sampling technique to capture necessary data for the study. Besides, secondary data were collected from existing studies, journals and reports from ministries, parastatals and organizations.

\subsection{Sample Size and Sampling Technique}

In the study area, there are six different agricultural extension zones or stations. In each of the stations ten extension workers were sampled through purposive random sampling technique. This method was adopted in order to facilitate the effectiveness and efficiency of data collection. In this regard, the questionnaire was 
administered among a total sample of 60 respondents. The sample was considered adequate to reflect the opinions of entire agricultural extension workers in the study area.

\subsection{Analytical Techniques}

The study employed both descriptive and inferential statistics to analyse the data. The descriptive statistics involving calculation of averages, percentages, mean and considered appropriate since it is the simplest and popular way of getting quick and reliable results. In addition, the statistical package for social sciences (SPSS) software was used particularly Chi square statistical technique to test the stated hypothesis and they are:

(i) There is no significant difference between agricultural extension workers' personal traits and their job performance in agricultural development.

(ii) There is no significant difference between respondents' attitudes and their job performance.

\section{Data Analysis and Discussion}

\subsection{Personal Characteristics of Respondents}

A glance at Table 1, it revealed that majority of the agricultural extension workers (50\%) fell within the age group of 21 and 60 years. The age of respondents that fell below 20 years (16.7\%) and those that above 61 years (8.3\%). It implies that majority of the agricultural extension workers were within the middle age. Considering gender variable, most of the respondents $(75.0 \%)$ were males, while $25.0 \%$ were females. The marital status revealed that about $33.3 \%$ were single while the remaining $66.7 \%$ of the extension workers were married. On the educational level, the respondents were literate and had formal western education. Majority of the extension workers (36.7\%), possess either National Certificate of Education (NCE) or Ordinary National Diploma (OND). About (16.7\%) of respondents had Secondary School Certificate while (13.3\%) had Primary School Leaving Certificate and (3.3\%) possessed postgraduate degrees.

Regarding income status of the extension workers, the study revealed that $(20.0 \%)$ of the workers considered the income they earn adequate while $(16.7 \%)$ of respondents considered their income to be fairly adequate. Indeed, majority of the workers $(33.3 \%)$ considered their income to be inadequate. The remaining respondents that is, those that considered their income to be fairly inadequate $(23.3 \%)$ and some of them $(6.7 \%)$ could not decide.

\subsection{Job Performance}

A cursory look at Table 2 revealed the rating of job performance of the agricultural extension workers in the study area. The score index was extracted from a set of questions of which the respondents were asked to rank the variables ranging from one for minimum to five for maximum.

Table 2 revealed that $(20.0 \%)$ of the extension workers had low job performance. Indeed, majority of them (75.0\%) that is, about three quarters of the workers had average performance while (5.0\%) had high performance. Considering overall job performance by the agricultural extension workers, the results showed an optimal level of job performance in the study area. Indeed, the result may be related to their attitudes to agricultural development as revealed by their attitude scores. To enhance job performance of workers, Bessette (2004) believed that organizations must create those conditions necessary for employees to be motivated to achieve the task required to satisfy organizational goals.

\subsection{Impediments to Job Performance}

The scores in respects of attitudes of the agricultural extension workers on the impediments to job performance were presented in Table 3. There was a divergent opinion expressed by the respondents. While some (53.3\%) disagreed, there was other $(25 \%)$ that agreed with poor conditions of service as a constraint to work performance. Also, half of the respondents (50.0\%) agreed while (25.0\%) disagreed with low social interaction as a constraint to their job performance.

An equal proportion $(45.0 \%)$ of the agricultural extension workers either agreed or dis-agreed that irregular payment of wages and allowance affected their job performance. This is true to a large extent in that money, fringe benefits and good working conditions are extremely important in boosting the morale of employees' performance (Schultz \& Germars, 1998). Indeed, a large percentage of the respondents agreed that the following factors were impediments to job performance namely: unnecessary delay in promotion (53.3\%); inadequate important tools to work $(51.7 \%)$ and inaccessibility to in-service training. In addition, a good percentage of the extension workers expressed feelings against monotony and boring work (50.0\%), insecurity of job (46.7\%), poor quality of supervision $(53.3 \%)$, lack of organizational standards $(53.3 \%)$, inability to work in rural environment (46.7\%) and that the work was tedious (56.7\%). 


\subsection{Attitude of Respondents to Work}

The attitude score of the agricultural extension workers was presented in Table 4 . The attitude score was categorized into bottom, middle and upper. Majority of the extension worker $(63.3 \%)$ had average attitude towards the job. But $(20.0 \%)$ exhibited poor attitude toward the job, while $(16.7 \%)$ had high attitude towards the job. The study showed that only very few extension workers had low attitude score. This implies that majority of the agricultural extension workers do so out of interest in the job and therefore still have a high attitude inspite of identified impediments as indicated earlier. Most people working as extension workers in the views of Schultz and Germars (1998) do so because of their concern for the living conditions of the rural populace, hunger, lack of good health care, malnutrition and also unemployment. The extension services are therefore an expression of voluntary commitment to the agricultural development in their respective stations.

\subsection{Test of Hypotheses}

Null hypothesis 1: There is no significant difference between respondents' personal traits and their job performance in agricultural development.

Null hypothesis 2: There is no significant difference between respondents' attitudes and their job performance.

A cursory look at Table 5, it revealed that there was no significant difference between age, gender, marital status and work performance of the respondents. However, educational status, income and attitude showed a significant difference with job performance at 0.05 levels. Therefore, the null hypothesis is rejected. These results are in line with the findings of Aquilar and Bigsten (1993), which revealed that personal characteristics such as age, marital status and gender of workers are not sufficient to account for differences in their job performance level.

Indeed, variations in income and educational levels were also found to affect job performance. The attitude score of the respondents is a reflection of their job performance score as indicated earlier.

\section{Concluding Remarks}

The results of this study showed agricultural extension workers were predominantly males (75.0\%). They were mostly married with about (66.7\%) within the age category of between 21 and 40 years. A simple majority of the respondents earned adequate income. It was observed that the job performance and attitude score were relatively high with $63.3 \%$ and $75.0 \%$ respectively. Agricultural extension workers' responses to some impediments to job performance such as poor condition of service, low and irregular wages, inadequate important materials and tools to carry out work were worth addressing by the ministries and agency concerned. A significant difference was found to exist between education, and attitude and job performance. There was also a significant difference among the respondents in the ranking of constraints to job performance. In this regard, young and qualified personnel who have interest in agricultural development should be employed to do the job and government at federal, state and local levels should strive to provide solutions to the constraints that affect job performance of the extension workers.

\section{References}

Adefila, J. O. (2008). Understanding economic growth and development in Nigeria: The relevance of core-periphery spatial inequality theory. Sahel Analyst, Journal of the Faculty of Social and MANAGEMENT Sciences, 10 (1), 86-95.

Adefila, J. O. (2008). Pattern of development in Plateau State: An inter-local government analysis for planning. Journal of Environmental Research and Policies, 3 (3), 101-106.

Adefila, J. O. (2011). An assessment of global warming effects on socio-economic development in sub-Saharan Africa. Paper presented at the International Conference on climate change: risks and opportunities organized by Nigerian Meteorological Society (NIMETS) held at the Department of Geography. Ahmadu Bello University. Zaria. $14^{\text {th }}-17^{\text {th }}$ November, 2011.

Adisa, B., \& kunade, E. O. (2005). Women in Agricultural and Rural Development. In: Adedoyin, S. F. (ed). Agricultural Extension in Nigeria. Ilorin: Agricultural Extension Society of Nigeria. pp. 69-77.

Aguilar, R., \& Bigsten, A. (1993). An analysis of differences in technical efficiency among Kenyan small-holders. Eastern African Economic review, 9 (2).

Appleton, S., \& Arsene, B. (1996). Education and Agricultural productivity: Evidence from Uganda. Centre for the study of African Economies. University of Oxford working paper series.

Baba, J. M. (1988). Population and rural development. Nigerian Institute of Social and Economic Research (NISER). Ibadan. 
Beti, Thompson, David M. Burns William R. Lynn, \& Donald Shopland. (2004). Community Based Interventions for Smokers. The Commit Field Experience. Diane Publishers.

Bessete G. (2004). A Guide to Participation Development Communication (pp. 80 - 109). IDRC Publishers.

Bindish, V., \& Robert, E. (1993). Evaluation of the performance of T \&V extension in Kenya. World Bank Technical Paper No. 208. World Bank. Washington DC.

Birkhaenser, D. R. (1991). The economic impact of Agricultural extension. A review. Economic Development and Cultural Change. 39 (3), 607-650.

Feder, M., \& Rogers, S. (2002). The impact of Agricultural extension. The training and supervision in India. The World Bank Research Observer, 1 (2), 139-161. http://dx.doi.org/10.1093/wbro/1.2.139

Igbokwe, E. M., \& Ajala, A. A. (1995). Popular participation in rural development in Nigeria. In Eboh E.C, Okoye; C.U, and Ayichi, D. (eds). Rural Development in Nigeria Concepts, Processes and Prospects (pp. 241 248). Enugu, Auto-Century Publishing Company Ltd.

Kuhnen, F. (2002). Sustainability, regional development and marginal locations. Applied Geography and Development, 39, 101-105.

Jibowo, A. A. (2005). History of agricultural extension in Nigeria. In: Adedoyin S. F. (ed), Agricultural Extension in Nigeria (pp. 1-12). Ilorin: Agricultural Extension Society of Nigeria.

Jones, G. E., \& Garforth, C. (1997). The history, development, and future of agricultural extension. In Swanson, B. Improving Agricultural Extension: A Reference Manual (3rd Edition)" FAO.

Mougeott, J. A. (2005). The world local organizations. The Social, Political and Enviromental Dimensions of Urban Agriculture. Agropolis. IDRC. Publishers.

Madukwe, M. C. (1995). Agricultural extension. systems and strategies. In Eboh, E. C, Okoye C. U. and Ayichi, D. (eds). Rural Development in Nigeria: Concepts, Processes and Prospects. Enugu: Auto-century Publishing Company Limited (pp. 265-273).

Nagel, U. J. (1997). Alternative approaches to organizing extension, in Swanson, B. Improving Agricultural Extension: A Reference Manual (3rd Edition) FAO.

Olatunbosun, D. (1995). Nigeria neglected rural majority. National Institute of Social and Economic Research (NISER). Ibadan.

Ogunfiditimi, T. G., \& Ewuola, S. O. (1995). Synthesis of Comparative Agricultural Extension Systems. Ibadan: Emmi Press Ltd.

Purcell, D., \& Anderson, J. R. (1997). Agricultural extension and research: Achievements and problems. The World Bank. Washington DC.

Schultz, T. P., \& Germars, M. (1998). Labour unions and the distribution of wages and employment in South Africa. Industrial and Labour Relation Review, 51 (4), 680-703.

Umali-Deininger, D. (1997). Public and private agricultural extension: Partners and rivals. The World Bank Research Observer, 12 (2), 203-224.

World Bank. (1990). Staff Appraisal Report: Kenya Second National Agricultural Extension Project. Washington DC. 
Table 1. Characteristics of respondents

\begin{tabular}{|c|c|c|c|}
\hline Variable & Category & Frequency & $\%$ \\
\hline \multirow{4}{*}{ Age } & $0-20$ & 10 & 16.7 \\
\hline & $21-40$ & 30 & 50.0 \\
\hline & $41-60$ & 15 & 25.0 \\
\hline & 61 and above & 5 & 8.3 \\
\hline \multirow{2}{*}{ Gender } & Male & 45 & 75 \\
\hline & Female & 15 & 25 \\
\hline \multirow{3}{*}{ Marital Status } & Single & 20 & 33.3 \\
\hline & Married & 40 & 66.7 \\
\hline & Divorced & 0 & 0 \\
\hline \multirow{6}{*}{ Education } & Primary school & 8 & 13.3 \\
\hline & Secondary school & 10 & 16.7 \\
\hline & $\mathrm{ND} / \mathrm{NCE}$ & 22 & 36.7 \\
\hline & HND/B. Sc. & 18 & 30 \\
\hline & PGC/M. Sc/Ph. D & 2 & 3.3 \\
\hline & Others & 0 & 0 \\
\hline \multirow{6}{*}{ Income } & Adequate & 12 & 20.0 \\
\hline & Fairly adequate & 10 & 16.7 \\
\hline & Inadequate & 20 & 33.3 \\
\hline & Fairly inadequate & 14 & 23.3 \\
\hline & Undecided & 4 & 6.7 \\
\hline & Others & 0 & 0 \\
\hline
\end{tabular}

Source: Field survey, 2010

Table 2. Job performance Score

\begin{tabular}{cccc}
\hline Performance Level & Range & Frequency & Percentage \\
\hline Low & $0-49$ & 12 & 20.0 \\
Average & $50-69$ & 45 & 75.0 \\
High & 70 and above & 3 & 5.0 \\
\hline
\end{tabular}

Source: Field survey, 2010 
Table 3. Impediments to Job Performance

\begin{tabular}{|c|c|c|c|c|c|c|c|c|c|c|}
\hline \multirow[t]{2}{*}{ Constraints } & \multicolumn{2}{|c|}{ S/Agree } & \multicolumn{2}{|c|}{ Agree } & \multicolumn{2}{|c|}{ Undecided } & \multicolumn{2}{|c|}{ Disagreed } & \multicolumn{2}{|l|}{$\begin{array}{c}\text { S/Dis } \\
\mathrm{a}\end{array}$} \\
\hline & Fre & $\%$ & Fre & $\%$ & Fre & $\%$ & Freq & $\%$ & Freq. & $\%$ \\
\hline Poor condition of service & 4 & 6.7 & 15 & 25.0 & 4 & 6.7 & 32 & 53.3 & 5 & 8.3 \\
\hline Low social interaction & - & - & 30 & 50.0 & 5 & 8.3 & 15 & 25.0 & 10 & 16.6 \\
\hline Irregular wages/allowance & 5 & 8.3 & 27 & 45.0 & - & - & 27 & 45.0 & 1 & 1.7 \\
\hline Delay in promotion & 2 & 3.3 & 32 & 53.3 & 4 & 6.7 & 22 & 36.7 & - & - \\
\hline Insecurity of job & 12 & 20.0 & 10 & 16.6 & 6 & 10.0 & 28 & 46.7 & 4 & 6.7 \\
\hline Inadequate important tools & - & - & 31 & 51.7 & 3 & 5.0 & 18 & 30.0 & 8 & 13.3 \\
\hline Low quality of supervision & 2 & 3.3 & 22 & 36.7 & 4 & 6.7 & 32 & 53.3 & - & - \\
\hline Repetitiveness of work & 5 & 8.3 & 18 & 30.0 & 2 & 3.3 & 30 & 50.0 & 5 & 8.3 \\
\hline No access to more training & 4 & 6.7 & 30 & 50.0 & - & - & 25 & 41.6 & 1 & 1.7 \\
\hline Lack of standards & 6 & 10.0 & 18 & 30.0 & 3 & 5.0 & 32 & 53.3 & 1 & 1.7 \\
\hline Cannot work in rural areas & 4 & 6.7 & 16 & 26.6 & 6 & 10.0 & 28 & 46.7 & 6 & 10.0 \\
\hline The work is tedious & 2 & 3.3 & 20 & 33.3 & - & - & 34 & 56.7 & 4 & 6.7 \\
\hline
\end{tabular}

Source: Field survey, 2010

Table 4. Attitude Score of Respondents

\begin{tabular}{cccc}
\hline Performance Level & Range & Frequency & Percentage \\
\hline Bottom & $0-30$ & 12 & 20 \\
Middle & $31-60$ & 38 & 63.3 \\
Upper & 61 and above & 10 & 16.7 \\
\hline
\end{tabular}

Source: Field survey, 2010

Table 5. Chi Square Test

\begin{tabular}{cccc}
\hline Variables & $\mathrm{X}^{2}$ Values & df & $\mathrm{P}$ \\
\hline Age & 7.575 & 8 & 0.333 \\
Gender & 16.201 & 4 & 0.253 \\
Marital status & 8.442 & 4 & 0.134 \\
Income & 12.220 & 4 & 0.008 \\
Level of Education & 18.016 & 8 & 0.027 \\
Attitude & 11.672 & 4 & 0.03 \\
\hline
\end{tabular}

Source: Field survey, 2010 